\title{
Expression Levels in Various Cell Lines of Natural Antisense Transcripts
}

\author{
Ayshan Rafat Yassin ${ }^{1}$, Bakhtiyar Shwan Azeez ${ }^{2}$ \\ ${ }^{1}$ lecturer, MSc Medical Biology Genetic, Medical Research Center/Hawler Medical University, Kurdistan \\ Region, Iraq \\ ${ }^{2}$ Assistant lecturer, MSc Medical Microbiology, Veterinary Department/ Shaqlawa Technical College/ Erbil \\ Polytechnic University, Kurdistan Region, Iraq \\ Corresponding author: Ayshan Rafat Yassin, aishanku@yahoo.com
}

\begin{abstract}
Background and objectives: lncRNAs (long non-coding RNAs) are important regulators of eukaryotic gene expression drew great attention recent years to uncover their importance for diagnostic, prognostic and therapeutic purposes because of their dysfunctions leads to diseases including cancer. TSIX consider a new regulator of collagen expression which stabilizes the collagen mRNA. HAGLR is a critical regulator for carcinogenesis and metastasis in different types of cancers. LCMT-1 is a negative regulator of Aktproto-oncogene. Our study aimed to investigate the level of mRNA expression and screening of genes by gel electrophoresis of TSIX, HAGLR, LCMT-1, and NOV2AS1 genes in breast cancer and normal group.

Methods: To explore their roles, ATCC normal (Beas2B, CRL4010, CRL8798) and cancer (A549, MCF7, MDA-MB-231, CRL2329) cell lines were subjected to examination through RNA isolation, cDNA conversion, Semiquantitative (by agarose gel and ImageJ program)and quantitative RT-PCR for expression analyses.
\end{abstract}

Results: Among the potential clinical utilities of lncNATs, they are of high interest for cancer treatment, even though the biological significance remains still under scientific investigation with major key questions yet to be elucidated. We hypothesized that lncNATsTSIX, HAGLR, LMCT1AS, and NAV2AS5 might have important roles for several tumorigenic processes.

Conclusions: TSIX, HAGLR, LMCT1AS, and NAV2AS5 genes have differential expression patterns in normal and cancer cell lines. The obtained results indicate their importance for biological processes in cancer.

Keywords: Cancer, Natural Antisense, Cell line, TSIX, HAGLR, LMCT1AS, NAV2AS5 


\section{Proceeding of the $2^{\text {nd }}$ Scientific Conference on Women's Health 2-3 September 2020 - Hawler Medical University}

\section{INTRODUCTION}

Non-coding RNAs (ncRNAs) have gained another dimension with new findings. Long-coding RNAs (lncRNAs) are a broad and diverse class of transcriptional RNA molecules that do not encode proteins with more than 200 nucleotides in length. Many lncRNAs, including transposons, pseudogenes, and simple repetitions that are biologically important functional regulators, are transcribed from genomic regions called 'trash' $(2,3)$. LncRNAs are becoming more and more important as a research topic related to cancer. So far, many lncRNA molecules have been identified that have roles in cancers. Some LNCRs act as tumor suppressors, while others behave like oncogenes. It is reported that many lncRNAs such as MALAT1, H19, and HOTAIR, which act as oncogenes in many cancers such as lung cancer, colon cancer, liver cancer, breast cancer, etc. $(4,8)$. There are many lncRNA that act as tumor suppressors. Brain (2017) reported that MEG3 acts as a tumor suppressor in many cancer types (9). IncRNAs act by enhancing or decreasing expression levels by binding to non-coding or protein-encoding RNAs. Natural antisense transcripts (NATs), complementary to protein-coding or non-coding RNA sequences, are important regulators of eukaryotic gene expression. Natural antisense transcripts (NATs) that bind to long non-coding RNAs (lncRNAs) called lncNATs. There were not enough studies yet for a new class of lncNATs. TSIX acted as a unique regulator expression that stabilizes the mRNA (5), XIST, and TSIX transcription regulated by X to Autosome ratio that stabilizes the transcription factor (9). Dysregulation of lncRNAsin various cancer cells serves as oncogenes or tumor suppressors. Long non-coding RNA HOXD-AS1 has a role in the development of different cancers, including neuroblastoma and breast cancer. HOXD-AS1 Regulates proliferation in prostate cancer (18). We hypothesized that TSIX, HOXDAS1/HAGLR, LCMT1AS, and NAV2AS5 antisense might be regulated by each other for several biological processes in cancer. The other hypothesis for selecting these four types of genes in our study is that all of them may have roles as tumor suppresser. We checked TSIX, HOXD-AS1/HAGLR, LMCT1AS, and NAV2AS5 antisense transcripts in normal cells (CRL4010, CRL8798) and cancer cells (MCF7, MDA-MB-231, CRL2329). These are commercially available cell lines from the ATCC. Until now, it is still a matter of debate whether TSIXis acting as an oncogene or as a tumor suppressor. There are many lncRNAs targeting proteins that bind to DNA (18-20). LncRNAs act with proteins that bind to DNA to regulate the transcription of DNA epigenetically (10). The interaction of TSIX with long coding RNAs is still open to research. Therefore in this thesis, we aim to find the interactive 


\section{Proceeding of the $2^{\text {nd }}$ Scientific Conference on Women's Health 2-3 September 2020 - Hawler Medical University}

role between lncRNA TSIX, HOXD-AS1/HAGLR, NOV2AS5, and LCM1AS in cancer. We would also like to address the respective role of TSIX, HOXD-AS1/HAGLR, NOV2AS5, and LCM1AS in cancer. This study will open a new avenue in cancer therapy by understanding their oncogenic or tumor-suppressive role and finding new therapeutic targets.

Long non-coding RNAs (lncRNAs) have a major effect on the health problem in all countries and predominantly affect different (1). The lncRNAs are the most common type of gene regulation in women and men responsible for most cancer-related gene expression and regulate the sequence of non-coding RNA. Many attempts have been done on the kinds and biology of cancers for many years. Studies have been showing that the cancer cell loses its death mechanisms and behaves like pseudo embryonic cells. lncRNAs are thought to nearly 30,000 due to in humans transcript, the non-coding transcriptome major part of lncRNA, invented lncRNA transcripts account was still done as the preliminary stage (2).

The human genome consists of more than $2 \mathrm{~m}$ of linear DNA that is inserted into a threedimensional structure in the nucleus of each cell (1). Molecular biology of the central doctrine suggested that the flow of genetic information is from DNA to RNA and from RNA to protein. However, in the last decade, this dogma has gained new dimensions with discovering noncoded RNAs (ncRNAs) (3).

The shortest ncRNAs were the most abundant RNA type, with the discovery of a few dozen short ncRNAs $(5,6)$ included cDNAs carrier RNA (tRNA), some ribosomal RNA (rRNA), splicing RNAs small nuclear RNAs (snRNAs) required for basic aspects of cell biology, transcription initiation RNAs, short RNAs associated with promoters, RNAs derived from 3'UTR, and various RNAs that have recently been observed associated with protein-encoding gene transcription (5).

The small interfering RNAs (siRNAs) acts as mRNA degradation mediators in the RNA interference (RNAi) process (7) then produced from long double-stranded dsRNAs of exogenous or endogenous origin (55). RNAi had a post-software gene silencing mechanism triggered by dsRNA's appearance in most eukaryotic cells (8). The first process of dsRNA was done by Dicer into small RNA pairs of length 21-23 nucleotides (nt), characterized by 2-nt 3'hydroxyl protruding ends called siRNA pairs and 5 phosphatidylcholines $(12,13)$. Subsequently, a strand of the siRNA double strand was incorporated into the RNA-induced silencing complex (RISC) to direct sequence-specific degradation of the substrate mRNA $(58,59)$. 


\section{Proceeding of the $2^{\text {nd }}$ Scientific Conference on Women's Health 2-3 September 2020 - Hawler Medical University}

Synthetic siRNAs were usually produced by solid-phase chemical synthesis methods that allow for the production of modified siRNAs. Small double-stranded siRNAs were transferred to the cells into which the guide strand was loaded into the RISC; this activated protein-nucleic acid complex that silences the gene by providing excellent complementarity and breaking down the mRNA by binding to a single target mRNA sequence showed in (Fig. 1.1) (60).

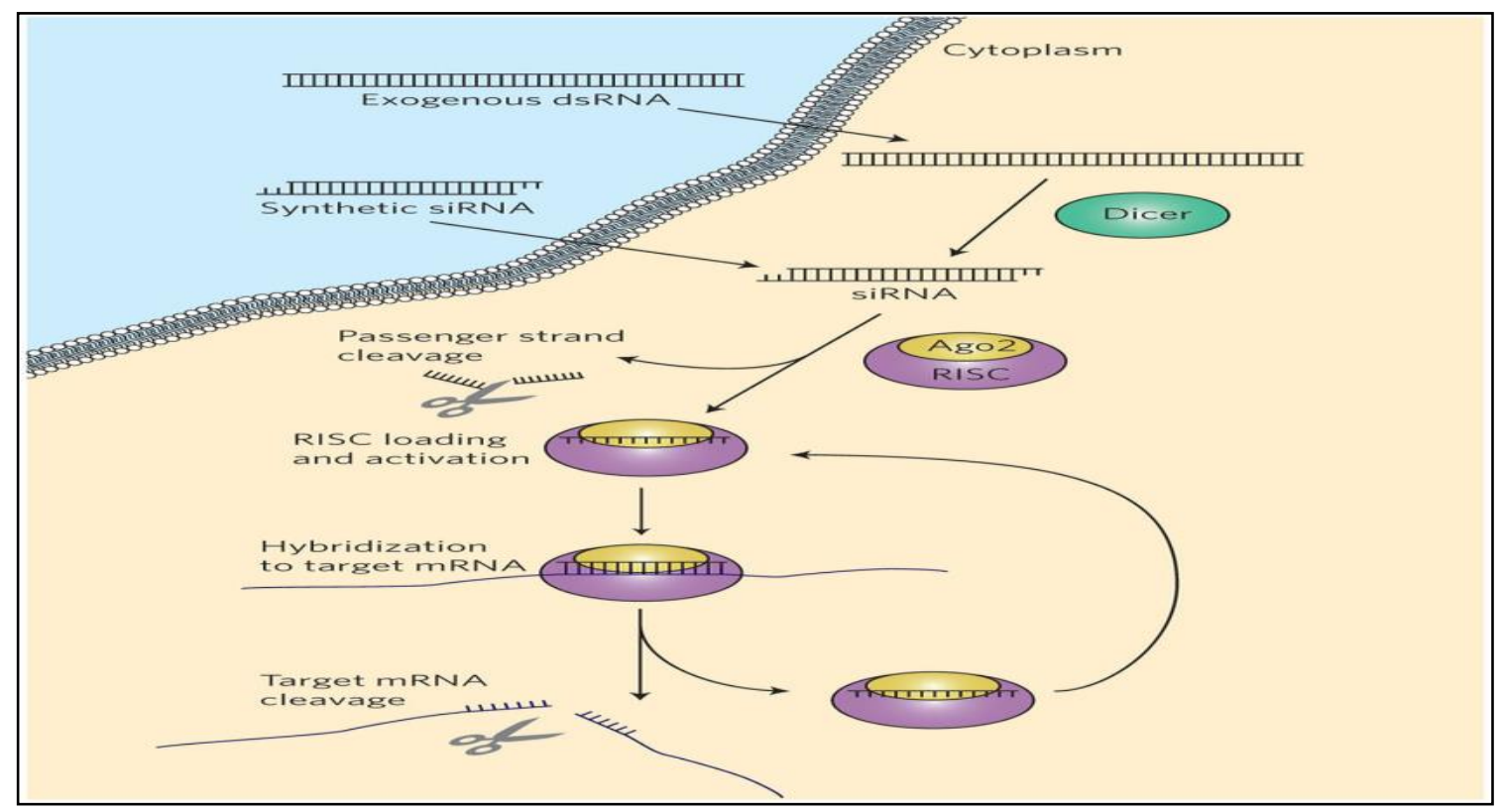

Figure 1.1: RNA intervention. The long dsRNA entering the cytoplasm,

\section{Cancer}

Breast cancer is considered one of the common cancers. Despite developing treatment methods, breast cancer cannot be treated effectively. Therefore, identifying novel biomarkers that will be important in the treatment and diagnosis of breast cancer was of great interest. Cancer was a leading cause of death throughout the world; from a total of 58 million death worldwide in 2005 , cancer accounts for 7.6 million or $13 \%$ of all death (64).

Cancer is defined as a generic term that encompasses more than 100 diseases that affected any part of the body. The world cancer only applied to malignant tumors; therefore, all cancer was malignant (61). Tumors may be either benign or malignant and are believed to emerge only when immune surveillance fails - the two important differences between benign and malignant tumor invasion and spread (62). 


\section{Proceeding of the $2^{\text {nd }}$ Scientific Conference on Women's Health 2-3 September 2020 - Hawler Medical University}

Breast cancer was a major health problem in all countries and predominantly affected the women population. In the United States, breast cancer was estimated to have 300-400 new cases related to death. According to 2014 cancer statistics in Turkey, breast cancer $(24.9 \%)$ was the most common cancer of women in all age groups (63).

\section{Metastasis}

Metastasis of breast cancer was responsible for more than $90 \%$ of patients' death. lncRNAs had an important role in transcribed RNA molecules with more than 200 nucleotides in the sequence. Suggested that abnormal expression of lncRNAs were involved in various biological functions such as metastasis, apoptosis, proliferation, and differentiation by effective epigenetic, transcriptional or post-transcriptional, splicing, and regulators that cause many diseases (51).

The amount of non-coding protein RNA was revealed in the genome sequencing technique. These ncRNAs consist of small nucleolar RNAs (snoRNAs), microRNAs (miRNAs), piwiinteracting RNAs (piRNAs), small interfering RNAs (siRNAs) (52).

Immunotherapy and chemotherapy succeeded in reversing the progression of breast cancer $(14,15)$.

\section{Materials and Methods}

\section{Collection of cell lines:}

In this study, $1 \mathrm{ml}$ of cell line samples were collected to isolate RNAs from 7different cell lines. Samples were stored at $-80{ }^{\circ} \mathrm{C}$ in Eppendorf tubes to be used for RNA isolation.

Table 2.1. Information of 7 cell line patients:

\begin{tabular}{|c|c|c|c|c|c|c|}
\hline No. & $\begin{array}{l}\text { NAME } \\
\text { OF } \\
\text { CELL }\end{array}$ & $\begin{array}{l}\text { Name of } \\
\text { tissue }\end{array}$ & $\begin{array}{l}\text { Biosafety } \\
\text { Level }\end{array}$ & Organism & $\begin{array}{l}\text { Cell } \\
\text { Type }\end{array}$ & nationality \\
\hline 1 & CRL2329 & $\begin{array}{l}\text { Breast } \\
\text { cancer }\end{array}$ & 1 & $\begin{array}{l}\text { Homo } \\
\text { sapiens }\end{array}$ & Lobular & U.S \\
\hline 2 & CRL4010 & $\begin{array}{l}\text { Breast } \\
\text { normal }\end{array}$ & 1 & $\begin{array}{l}\text { Homo } \\
\text { sapiens }\end{array}$ & epithelial & U.S \\
\hline 3 & MDAMB & breast cancer & 1 & $\begin{array}{l}\text { Homo } \\
\text { sapiens }\end{array}$ & Ductal & U.S \\
\hline 5 & CRL8798 & $\begin{array}{l}\text { Normal } \\
\text { breast }\end{array}$ & 1 & $\begin{array}{l}\text { Homo } \\
\text { sapiens }\end{array}$ & lobular & U.S \\
\hline 6 & MCF7 & $\begin{array}{l}\text { Breast } \\
\text { cancer }\end{array}$ & 1 & $\begin{array}{l}\text { Homo } \\
\text { sapiens }\end{array}$ & Tumor & U.S \\
\hline
\end{tabular}




\section{Cell Culture}

All cell lines were grown in Dulbecco's modified Eagle's medium (DMEM) supplemented with $10 \%$ fetal bovine serum, $100 \mathrm{U} / \mathrm{mL}$ penicillin, and $100 \mathrm{mg} / \mathrm{mL}$ streptomycin in a humidified atmosphere containing $5 \% \mathrm{CO} 2$ at $37{ }^{\circ} \mathrm{C}$, at Medical Biology Department Cell Culture Lab., Gaziantep University.

\section{Primer Design}

For this study, appropriate synthetic primers were designed for intron regions of TSIX, HAGLR, LCMT1AS, and NAV2AS5 genes using NCBI/Primer Blast database. Primer sequences, length, annealing temperature, GC content, and PCR product length of primers designed for intron sequences of TSIX, HAGLR, LCMTIAS, and NAV2AS5 genes were shown in Table 2.2 in a detailed manner.

Table 2.2. Lis of Primers used in the study:

\begin{tabular}{llcccc}
\hline & sequence $\left(\mathbf{5}^{\prime}->\mathbf{3}^{\prime}\right)$ & $\begin{array}{l}\text { Primer } \\
\text { length }\end{array}$ & $\begin{array}{l}\text { temperature } \\
\left({ }^{\circ} \mathbf{C}\right)\end{array}$ & GC\% & $\begin{array}{l}\text { PCR } \\
\text { product } \\
\text { (bp) }\end{array}$ \\
\hline TSIX & GTTGCATCAGCTGTCCTCCT & 17 & 57.75 & 64.71 & 221 \\
& AAAAAGGGGTTGGGGTAGG & 20 & 61.90 & 60.00 & \\
HAGLR & ACCAGACCTACTCTTCCGCT & 20 & 59.88 & 55.00 & 246 \\
& GGGAAGAGCCAAGTCAGAC & 20 & 60.03 & 55.00 & \\
LCMT1A & ATCTGGTGAGCCAGGTAGG & 20 & 59.53 & 55.00 & 207 \\
S & A & & 59.44 & 52.38 & \\
NOV2AS & GGGAAGAGCCAAGTCAGAC & 21 & 50.00 & \\
& CCCACTGTGAGAACCCCTTC & 20 & 59.96 & 609 \\
& GAGACCCATGCCAGTGTGT & 20 & 60.96 & 60.00 & 209 \\
\hline
\end{tabular}

\section{RNA Isolation from cell line}

After cells reach 80-90\% density, they were removed for RNA isolation under appropriate conditions. RNA was extracted from cell culture using an RNA isolation kit (Roche, Mannheim, Germany) kit.RNA isolation protocol has been done as follows; The cells with appropriate density were removed with Trypsin, and DMEM containing FCS was added to stop the effect of Trypsin. Cells were centrifuged at $3500 \mathrm{rpm}$ for $5 \mathrm{~min}$. The supernatant was removed without touching the pellet. The remaining pellet resuspended in $200 \mu 1$ PBS.- Add $400 \mu \mathrm{l}$ of Lysis Buffer to this mixture and vortex for 15 seconds. The whole mix transferred to filter tubes, centrifuged for 30 seconds at $9200 \mathrm{rpm}$. The lower part was discarded. Adding 100 
$\mu \mathrm{l}(10 \mu \mathrm{l}$ DNAse and $90 \mu \mathrm{l}$ DNAse incubation buffer) to the filtered tubes and wait at room temperature for 45 minutes. Add $500 \mu \mathrm{l}$ Wash Buffer I and centrifuged at $9200 \mathrm{rpm}$ for 30 seconds. The lower part was discarded. Then adding $500 \mu \mathrm{l}$ Wash Buffer II and centrifuged at $9200 \mathrm{rpm}$ for 30 seconds. The bottom tube was replaced with the new one. $200 \mu \mathrm{l}$ of wash Buffer II added and centrifuge for 2 minutes at $11800 \mathrm{rpm}$. The lower tube was discarded, and a new tube was inserted. Finally, Adding $50 \mu \mathrm{l}$ of Elution Buffer and wait for 1 minute at room temperature. Centrifuge at $9200 \mathrm{rpm}$ for 1 minute. The filtered tube was discarded. Measurements were made on the NanoDrop 1000 to determine the amount of RNA.RNAs were stored at $-80^{\circ} \mathrm{C}$ until the working period.

\section{RESULTS}

Gene expression results of HAGLR, TSIX, NOV2AS5, and LCMT1AS in different cell lines expression levels of TSIX, HAGLR, NOV2AS5, LCMT1AS has been analyzed in 7 different human cell line. Gene expression analyzes were performed by Real-Time PCR methods (Figure

\section{a. The expression level of HAGLR in breast cancer cell lines}

The expression level of HAGLRhave been shown in 5 different cell lines. Gene expression analyzes were performed by Real-Time PCR methods (Figure 3.1). HAGLR has been shown to have the highest expression level in CRL2329 cells for breast cancer, followed by expression level in the MCF7, MDA-MB-231, CRL2329, CRL4010 cell line.

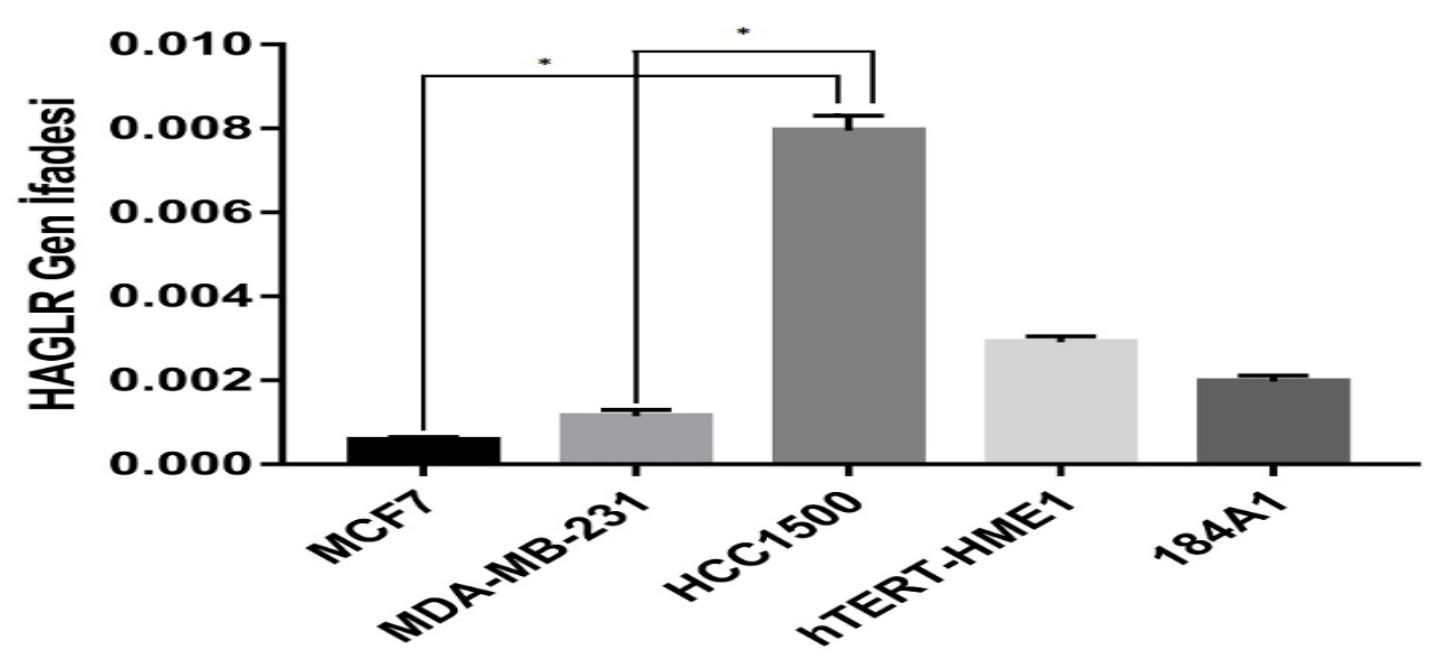

Figure 3.1: HAGLR is expressed mostly in breast cancer, and the control group was found to show expression cancer and normal cell line. 


\section{b. The expression level of TSIX in breast cancer cell lines}

The expression level of TSIX has been shown in 5 different cell lines. Gene expression analyzes were performed by Real-Time PCR methods (Figure 3.2).

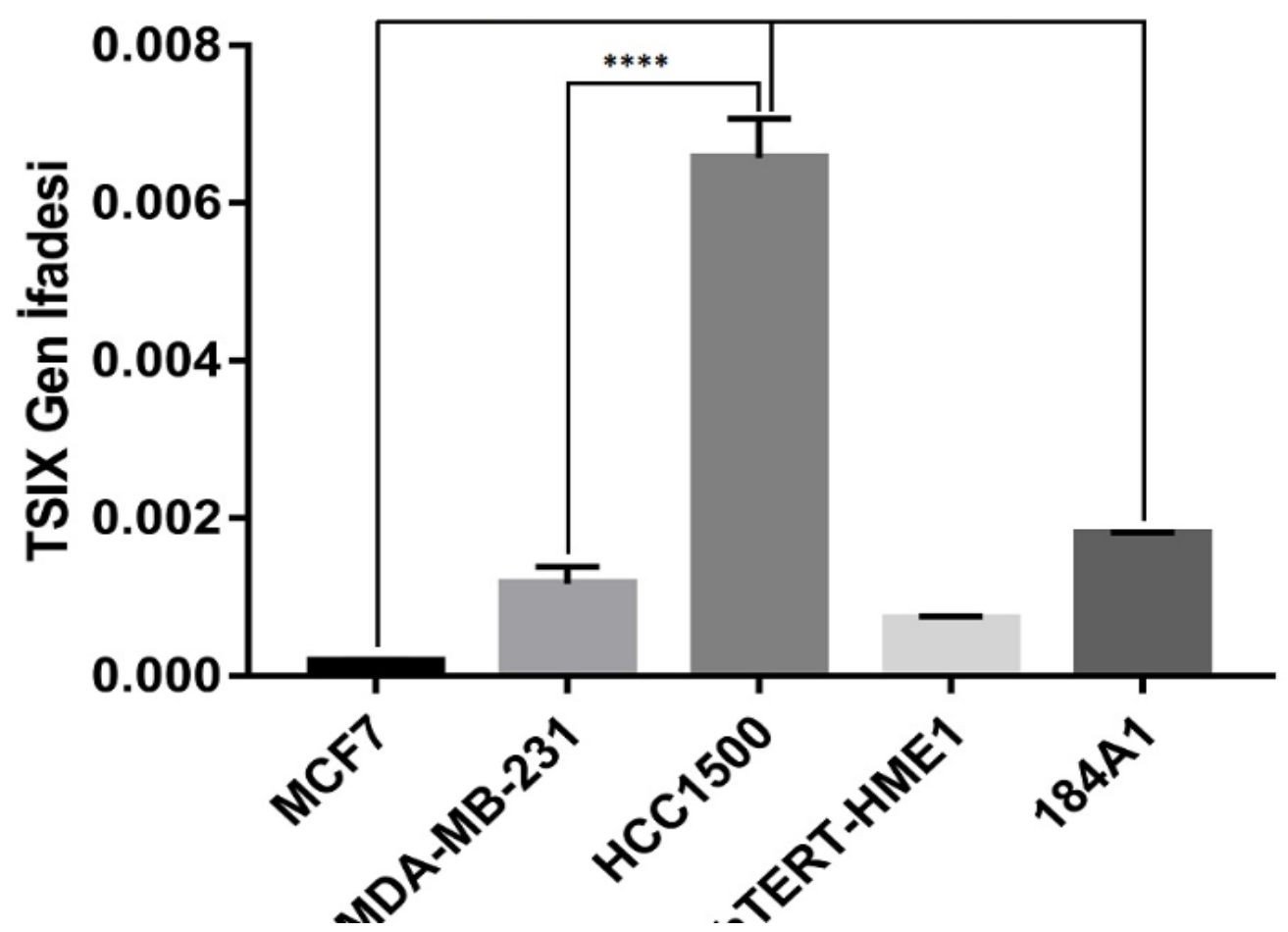

Figure 3.2: TSIX is expressed mostly in breast cancer and the control group was found to show expression cancer and normal cell line.

\section{c. Expression level in NOV2AS5 of breast cancer cell line}

The expression level of NOV2AS5has been shown in 5 different cell lines. Gene expression analyzes were performed by Real-Time PCR methods (Figure 3.3). NOV2AS5has has been shown to have the highest expression level in CRL2329 cells for breast cancer, followed by expression in the MCF7, MDA-MB-231, CRL2329, CRL4010 cell line. NOV2AS5was found to be the lowest in MCF7, MDA-MB-231, CRL2329, CRL4010, control group, and cancer group. 


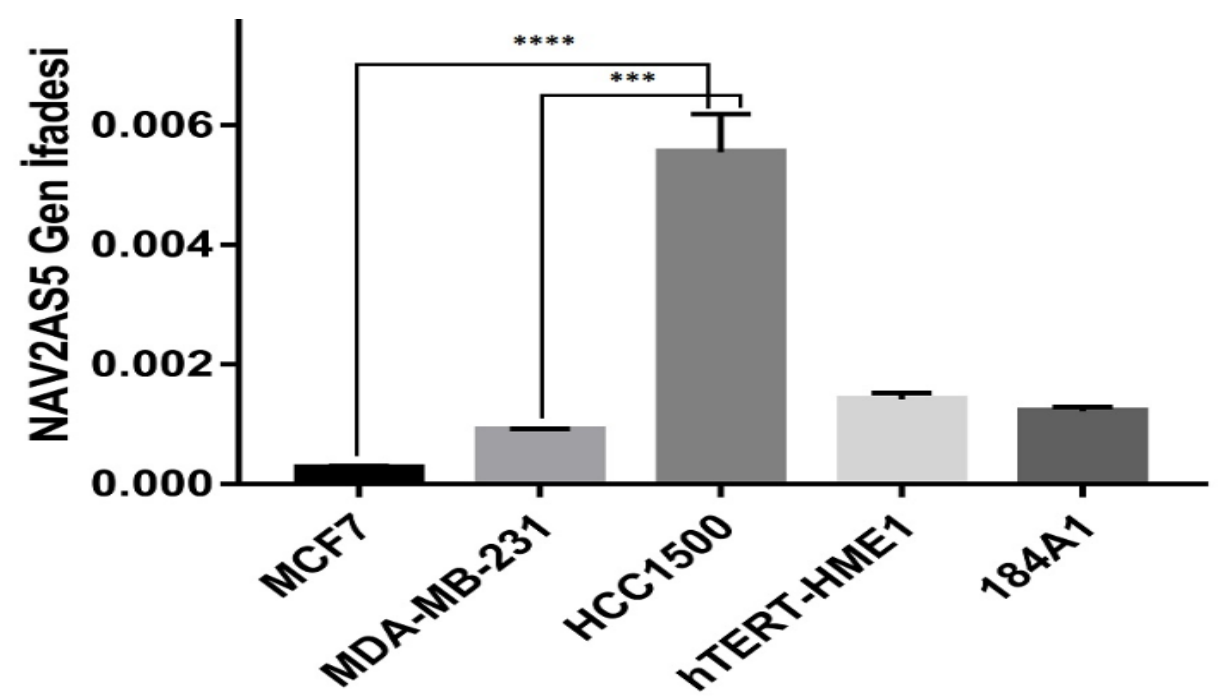

Figure 3.3: NOV2AS5 is expressed mostly in breast cancer and the control group was found to show expression cancer and normal cell line.

\section{d. The expression level of LCMT1AS in breast cancer cell lines}

The expression level of LCMT1AShas been shown in 5 different cell lines. Gene expression analyzes were performed by Real-Time PCR methods (Figure 3.4). LCMT1AS has been shown to have the highest expression level in CRL2329 cells for breast cancer following expression in the MCF7, MDA-MB-231, CRL2329, CRL4010 cell line. LCMT1AS was found to be the lowest in MCF7, MDA-MB-231, CRL2329, CRL4010, control group, and cancer group.

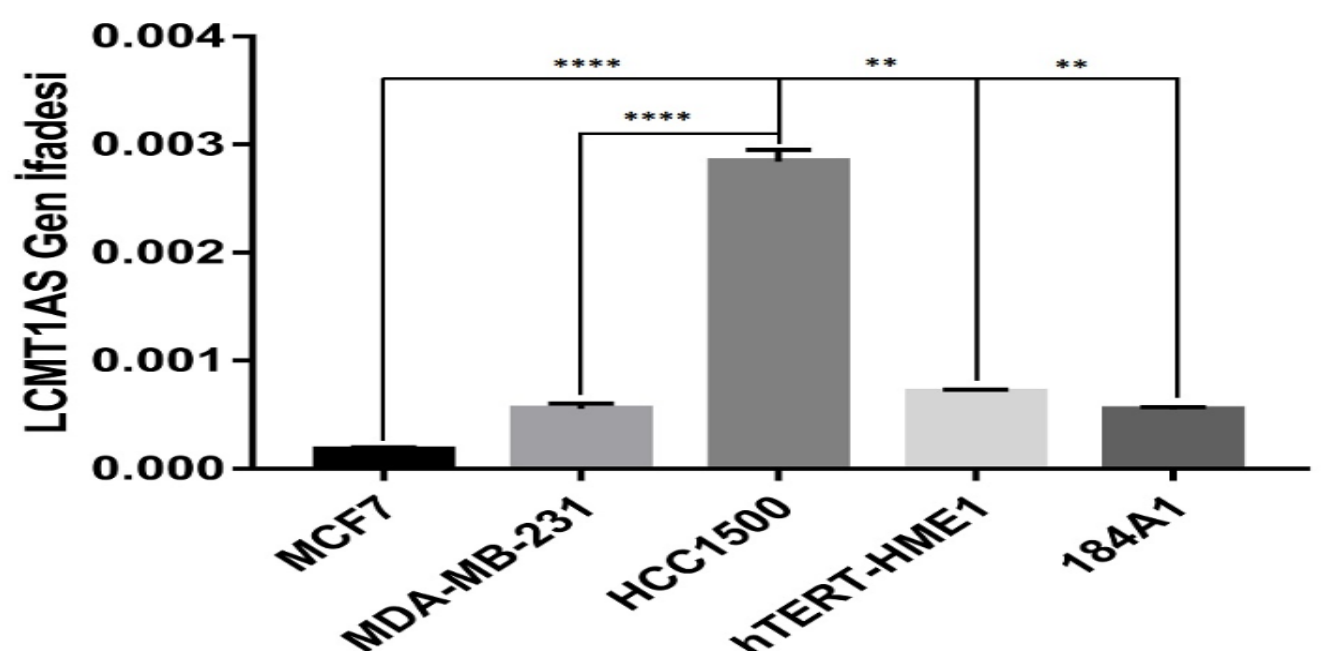

Figure 3.4: LCMT1AS5 is expressed mostly in breast cancer and the control group was found to show expression cancer and normal cell line. 


\section{Proceeding of the $2^{\text {nd }}$ Scientific Conference on Women's Health \\ 2-3 September 2020 - Hawler Medical University}

\section{DISCUSSION}

LncRNAs (long non-coding RNAs), with various important molecular and cellular functions and NATs, complementary to protein-coding or non-coding RNA sequences are important regulators of eukaryotic gene expression drew great attention recent years to uncover their importance for diagnostic, prognostic, and therapeutic purposes because of their dysfunctions leads to diseases including cancer. Earlier NATs were described as lncRNAs. This convergence between NAT and lncRNA determination raised confusion and gradually started to be disappeared with the increasing knowledge. Specific pcGen (protein-coding Gene) regulation by their corresponding ncNATs (non-coding NATs) has been reported. TSIX was a new regulator of collagen expression which stabilizes the collagen mRNA. HOXD-AS1/ HAGLR was a critical regulator for carcinogenesis and metastasis in different types of cancers. LCMT1 was a negative regulator of Akt proto-oncogene. Not so much information was available related to the NOV2AS1 gene. These four types of genes regulate cancer cell. We performed a comparison with the control group and cancer groups. The tumor suppressor genes (TSIX, HAGLR, LCMT-1, and NOV2AS1) were regulated downwards in the cancer cell line.

Studying cancer cells' molecular mechanisms will be base research for other related investigations and will create opportunities for new cancer therapy, especially breast cancer. The strategies regarding investigating these genes related to the cell cycle will help understand the anti-tumoral effect on target organs.

TSIX was a tumor suppressor gene. It was identified by the analysis of accumulated transcripts, including non-coding histone methyltransferase, which is responsible for trimethylation of the lysine of histone $\mathrm{H} 3$ and may have a role in the regulation of mRNA transcription factor (suppressing tumor development) (45).

The Gene expression level of tumor suppressor genes was identified by Real-Time PCR analysis. The seven types of cell lines of breast cancer and lung cancer were statistically comparable to the control group of their normal cell lines. It has been understood that under the normal condition, there was overexpression from cancer cell lines in comparison to the normal group.

The expression level of TSIX, HAGLR, NOV2AS5, LCMT1AS, and GAPDH genes in normal breast and cancer cell lines has been demonstrated by RT-PCR analysis. NOV2AS5 has higher expression than other genes.

In our findings, the expression level of TSIX, HAGLR, NOV2AS5, LCMT1AS genes was decreased (downregulated) as shown in figures 3.1, 3.2, 3.3, and 3.4 and statistically were 


\section{Proceeding of the $2^{\text {nd }}$ Scientific Conference on Women's Health 2-3 September 2020 - Hawler Medical University}

significant (Wilcoxon Signed Rank Test) $\mathrm{p}>0.05$. These results agree with results that reported the downregulated expression of TSIX, HAGLR, NOV2AS5, and LCMT1AS by (40).

Functional inactivation of TSIX in lncNAT may facilitate the development of a regulator tumor behavior (53). The role of TSIX and HAGLR in chromatin modification, the gene expression pathways disrupted by antisense activation that may lead to new treatment strategies for different tissues (55).

The balance between histone acetylation and deacetylation serves as a key epigenetic mechanism for gene expression, DNA repair, developmental processes, and tumorigenesis (56). Thus, any reason to make this imbalance can lead to abnormal cell function, even tumorigenesis (57). Yong Wang et al. (58) reported that hMOF an acetyltransferase of H4K16 might be involved in the pathogenesis of renal cell carcinoma. This epigenetic change might be a new CA9-independent RCC diagnostic marker.

A microRNA expression study suggested that tumor development and tumor progression include metastasis (59). Khella et al. (59) analyzed distant metastases with primary tumors and founded a distinct miRNA signature at metastases. Some of the primary tumor samples clustered together with the distant metastasis so that these primary tumors have a metastasisspecific signature (60).

In this study, mutated regions of TSIX, HAGLR, NOV2AS5, and LCMT1AS genes were analyzed by q PCR rote gene and sequence analysis. However, expression was observed in these regions. TSIX gene expression was compared from two groups disease and a normal group. We analyzed by ImageJ Program comprises two types of bromodomains in this study such as domain 1; and random region of TSIX, HAGLR, NOV2AS5, and LCMT1AS genes. In conclusion, the expression level of TSIX, HAGLR, NOV2AS5, and LCMT1AS genes had differential significant downregulated. Studying the molecular mechanisms of a tumor suppressor of the gene had aided the development of molecular-targeted therapy for breast cancer. To study the molecular mechanisms, we investigated between breast cancer and normal breast. Further analysis is needed.

We have prepared the groundwork for our next study, tumor suppressant effect or not. We found a result of this. For the next study, we can check the cell cycle for growth or not, or we can give siRNA for inhibiting gene expression or give specific miRNA for block gene target. 


\section{REFERENCES}

1- Gong C, Maquat LE. IncRNAs transactivate STAU1-mediated mRNA decay by duplexing with 3' UTRs via Alu elements. Nature. 2011 Feb;470(7333):284-8.

2. Tsai MC, Manor O, Wan Y, Mosammaparast N, Wang JK, Lan F, Shi Y, Segal E, Chang HY. Long noncoding RNA as modular scaffold of histone modification complexes. Science. 2010 Aug 6;329(5992):689-93.

3. Khalil AM, Guttman M, Huarte M, Garber M, Raj A, Morales DR, Thomas K, Presser A, Bernstein BE, van Oudenaarden A, Regev A. Many human large intergenic noncoding RNAs associate with chromatin-modifying complexes and affect gene expression. Proceedings of the National Academy of Sciences. $2009 \mathrm{Jul}$ 14;106(28):11667-72.

4. Gutschner T, Hämmerle M, Diederichs S. MALAT1—a paradigm for long noncoding RNA function in cancer. Journal of molecular medicine. $2013 \mathrm{Jul}$ 1;91(7):791-801.

5. Sana J, Faltejskova P, Svoboda M, Slaby O. Novel classes of non-coding RNAs and cancer. Journal of translational medicine. 2012 Dec;10(1):1-21.

6. Gibb EA, Brown CJ, Lam WL. The functional role of long non-coding RNA in human carcinomas. Molecular cancer. 2011 Dec;10(1):1-7.

7. Xu C, Yang M, Tian J, Wang X, Li Z. MALAT-1: a long non-coding RNA and its important 3 'end functional motif in colorectal cancer metastasis. International journal of oncology. $2011 \mathrm{Jul}$ 1;39(1):169-75.

8. Loos F, Maduro C, Loda A, Lehmann J, Kremers GJ, Ten Berge D, Grootegoed JA, Gribnau J. Xist and Tsix transcription dynamics is regulated by the X-to-autosome ratio and semistable transcriptional states. Molecular and cellular biology. 2016 Nov 1;36(21):2656-67.

9. Zhou Y, Zhong Y, Wang Y, Zhang X, Batista DL, Gejman R, Ansell PJ, Zhao J, Weng C, Klibanski A. Activation of p53 by MEG3 non-coding RNA. Journal of Biological Chemistry. 2007 Aug 24;282(34):24731-42.

10. Prensner JR, Chinnaiyan AM. The emergence of lncRNAs in cancer biology. Cancer discovery. 2011 Oct 1;1(5):391-407.

11. White NM, Cabanski CR, Silva-Fisher JM, Dang HX, Govindan R, Maher CA. Transcriptome sequencing reveals altered long intergenic non-coding RNAs in lung cancer. Genome biology. 2014 Aug;15(8):1-6. 


\section{Proceeding of the $2^{\text {nd }}$ Scientific Conference on Women's Health 2-3 September 2020 - Hawler Medical University}

12. Yang J, Lin J, Liu T, Chen T, Pan S, Huang W, Li S. Analysis of lncRNA expression profiles in non-small cell lung cancers (NSCLC) and their clinical subtypes. Lung cancer. 2014 Aug 1;85(2):110-5.

13. Wang KC, Chang HY. Molecular mechanisms of long noncoding RNAs. Molecular cell. 2011 Sep 16;43(6):904-14.

14. Chu EA, Kim YJ. Laryngeal cancer: diagnosis and preoperative work-up. Otolaryngologic Clinics of North America. 2008 Aug 1;41(4):673-95.

15. Gu P, Chen X, Xie R, Han J, Xie W, Wang B, Dong W, Chen C, Yang M, Jiang J, Chen Z. IncRNA HOXD-AS1 regulates proliferation and chemo-resistance of castrationresistant prostate cancer via recruiting WDR5. Molecular Therapy. 2017 Aug 2;25(8):1959-73.

16. Kesteloot HE, Zhang J. Differences in breast cancer mortality worldwide: unsolved problems. European journal of cancer prevention. 2006 Oct 1;15(5):416-23.

17. Tian L, Li M, Ge J, Guo Y, Sun Y, Liu M, Xiao H. MiR-203 is downregulated in laryngeal squamous cell carcinoma and can suppress proliferation and induce apoptosis of tumours. Tumor Biology. 2014 Jun;35(6):5953-63.

18. Tian L, Zhang J, Ge J, Xiao H, Lu J, Fu S, Liu M, Sun Y. MicroRNA-205 suppresses proliferation and promotes apoptosis in laryngeal squamous cell carcinoma. Medical Oncology. 2014 Jan 1;31(1):785.

19. Kushi LH, Kwan ML, Lee MM, Ambrosone CB. Lifestyle factors and survival in women with breast cancer. The Journal of nutrition. 2007 Jan 1;137(1):236S-42S.

20. Lotfi, M. H., S. Charkhati, and S. SHOBEYRI. "Breast cancer risk factors in an urban area of Yazd city, Iran. 2008: 258-264.

21. Casciato DA, Territo MC, editors. Manual of clinical oncology. Lippincott Williams \& Wilkins; 2009.

22. Couto E, Hemminki K. Estimates of heritable and environmental components of familial breast cancer using family history information. British journal of cancer. 2007 Jun;96(11):1740-2.

23. Jemal A, Siegel R, Xu J, Ward E. Cancer statistics, 2010. CA: a cancer journal for clinicians. 2010 Sep;60(5):277-300.

24. Siegel RL, Miller KD, Jemal A. Cancer statistics, 2016. CA: a cancer journal for clinicians. 2016 Jan;66(1):7-30. 


\section{Proceeding of the $2^{\text {nd }}$ Scientific Conference on Women's Health 2-3 September 2020 - Hawler Medical University}

25. Eliyatkın N, Yalçın E, Zengel B, Aktaş S, Vardar E. Meme Karsinomunda Moleküler Sinıflama: Gelenekselden Yeni Döneme Yolculuk. Meme Sagligi Dergisi/Journal of Breast Health. 2015 Apr 1;11(2).

26. Vuong D, Simpson PT, Green B, Cummings MC, Lakhani SR. Molecular classification of breast cancer. Virchows Archiv. 2014 Jul;465(1):1-4.

27. Gutschner T, Diederichs S. The hallmarks of cancer: a long non-coding RNA point of view. RNA biology. 2012 Jun 1;9(6):703-19.

28. Shtivelman E, Hensing T, Simon GR, Dennis PA, Otterson GA, Bueno R, Salgia R. Molecular pathways and therapeutic targets in lung cancer. Oncotarget. 2014 Mar;5(6):1392.

29. Callahan R. Oncogenes and breast cancer progression. Boundaries between Promotion and Progression during Carcinogenesis. 1991:143-56.

30. Macleod K. Tumor suppressor genes. Current opinion in genetics \& development. 2000 Feb 1;10(1):81-93.

31. Lee JA, Pallas DC. Leucine carboxyl methyltransferase-1 is necessary for normal progression through mitosis in mammalian cells. Journal of Biological Chemistry. 2007 Oct 19;282(42):30974-84.

32. Roshan Fatima, Vijay Suresh Akhade, Debosree Pal and Satyanarayana MR Rao,long non coding RNA development in cancer cell. 2015: 3:5.

33. Siegal R, Miller KD, Jemal A. Cancer statistics, 2012. Ca Cancer J Clin. 2014 Jan;64(1):9-29.

34. Balmain A. Cancer genetics: from Boveri and Mendel to microarrays. Nature reviews cancer. 2001 Oct;1(1):77-82.

35. Kroemer G. The proto-oncogene Bcl-2 and its role in regulating apoptosis. Nature medicine. 1997 Jun;3(6):614-20.

36. Eng C. RET proto-oncogene in the development of human cancer. Journal of Clinical Oncology. 1999 Jan;17(1):380-.

37. Li H, Ma SQ, Huang J, Chen XP, Zhou HH. Roles of long noncoding RNAs in colorectal cancer metastasis. Oncotarget. 2017 Jun 13;8(24):39859.

38. Dey BK, Mueller AC, Dutta A. Long non-coding RNAs as emerging regulators of differentiation, development, and disease. Transcription. 2014 Aug 8;5(4):e944014.

39. Dimova I, Popivanov G, Djonov V. Angiogenesis in cancer-general pathways and their therapeutic implications. Jbuon. 2014;19(1):15-21. 


\section{Proceeding of the $2^{\text {nd }}$ Scientific Conference on Women's Health 2-3 September 2020 - Hawler Medical University}

40. Khorshidi A, Dhaliwal P, Yang BB. Noncoding RNAs in tumor angiogenesis. The Long and Short Non-Coding RNAs in Cancer Biology. 2016:217-41.

41. Dey BK, Mueller AC, Dutta A. Long non-coding RNAs as emerging regulators of differentiation, development, and disease. Transcription. 2014 Aug 8;5(4):e944014.

42. Dimova I, Popivanov G, Djonov V. Angiogenesis in cancer-general pathways and their therapeutic implications. Jbuon. 2014;19(1):15-21.

43. Khorshidi A, Dhaliwal P, Yang BB. Noncoding RNAs in tumor angiogenesis. The Long and Short Non-Coding RNAs in Cancer Biology. 2016:217-41.

44. Michalik KM, You X, Manavski Y, Doddaballapur A, Zörnig M, Braun T, John D, Ponomareva Y, Chen W, Uchida S, Boon RA. Long noncoding RNA MALAT1 regulates endothelial cell function and vessel growth. Circulation research. 2014 Apr 25;114(9):1389-97.

45. Thum, Thomas, and Jan Fiedler. LINCing MALAT1 and angiogenesis. 2014: 13661368.

46. Jiang X, Yan Y, Hu M, Chen X, Wang Y, Dai Y, Wu D, Wang Y, Zhuang Z, Xia H. Increased level of $\mathrm{H} 19$ long noncoding RNA promotes invasion, angiogenesis, and stemness of glioblastoma cells. Journal of neurosurgery. 2016 Jan 1;124(1):129-36.

47. Schmitz SU, Grote P, Herrmann BG. Mechanisms of long noncoding RNA function in development and disease. Cellular and molecular life sciences. 2016 Jul;73(13):2491509.

48. Wilusz JE, Sunwoo H, Spector DL. Long noncoding RNAs: functional surprises from the RNA world. Genes \& development. 2009 Jul 1;23(13):1494-504.

49. Wang KC, Chang HY. Molecular mechanisms of long noncoding RNAs. Molecular cell. 2011 Sep 16;43(6):904-14.

50. Katayama S, Tomaru Y, Kasukawa T, Waki K, Nakanishi M, Nakamura M, Nishida H, Yap CC, Suzuki M, Kawai J, Suzuki H. Antisense transcription in the mammalian transcriptome. Science. 2005 Sep 2;309(5740):1564-6.

51. Faghihi MA, Wahlestedt C. Regulatory roles of natural antisense transcripts. Nature reviews Molecular cell biology. 2009 Sep;10(9):637-43.

52. Lin S, Zhang L, Luo W, Zhang X. Characteristics of antisense transcript promoters and the regulation of their activity. International journal of molecular sciences. 2016 Jan;17(1):9.

53. Wagner EG, Simons RW. Antisense RNA control in bacteria, phages, and plasmids. Annual review of microbiology. 1994 Oct;48(1):713-42. 


\section{Proceeding of the $2^{\text {nd }}$ Scientific Conference on Women's Health 2-3 September 2020 - Hawler Medical University}

54. Delihas N, Rokita SE, Zheng P. Natural antisense RNA/target RNA interactions: possible models for antisense oligonucleotide drug design. Nature biotechnology. 1997 Aug;15(8):751-3.

55. Caplen NJ. Gene therapy progress and prospects. Downregulating gene expression: the impact of RNA interference. Gene therapy. 2004 Aug;11(16):1241-8.

56. Cerutti H. RNA interference: traveling in the cell and gaining functions?. TRENDS in Genetics. 2003 Jan 1;19(1):39-46.

57. Denli AM, Hannon GJ. RNAi: an ever-growing puzzle. Trends in biochemical sciences. 2003 Apr 1;28(4):196-201.

58. Hammond SM, Bernstein E, Beach D, Hannon GJ. An RNA-directed nuclease mediates post-transcriptional gene silencing in Drosophila cells. Nature. 2000 Mar;404(6775):293-6.

59. Santarpia L, Calin GA, Adam L, Ye L, Fusco A, Giunti S, Thaller C, Paladini L, Zhang $\mathrm{X}$, Jimenez C, Trimarchi F. A miRNA signature associated with human metastatic medullary thyroid carcinoma. Endocr Relat Cancer. 2013 Dec 1;20(6):809-23.

60. Kanasty R, Dorkin JR, Vegas A, Anderson D. Delivery materials for siRNA therapeutics. Nature materials. 2013 Nov;12(11):967-77.

61. Australian Institute of Health. Australia's Health 2012: In Brief. AIHW; 2012.

62. Snustad DP, Simmons MJ, Jenkins JB. Principles of Genetics John Wiley \& Sons. Hoboken, NJ. 2003.

63. Siegel R, DeSantis C, Jemal A. Colorectal cancer statistics, 2014. CA: a cancer journal for clinicians. 2014 Mar;64(2):104-17.

64. World Health Organization. The world health report 2006: working together for health. World Health Organization; 2006 Mar 23. 